\title{
THREE OBSERVATIONS OF COLOUR BANDED SHOREBIRDS
}

\section{DALE G HJERTAAS AND PAULE HJERTAAS}

15 Olson Place, Regina, Saskatchewan, S4S 2J6

It is always exciting to watch shorebirds, but the chance to see a colour banded one and find out something of its history adds a special element to the experience. We have had the good fortune to observe a Hudsonian Godwit, a Pectoral Sandpiper and a Piping Plover carrying colour bands.

On May 12, 2013 we drove about 10 miles along grid 641 and other roads south of Pense, Saskatchewan looking for birds on wet fields. We observed a few shore birds including 5 Pectoral Sandpipers, one of which was banded. Through our binoculars we recorded the following bands: left leg - aluminum below knee and green flag with white above it, above knee; right leg - 2 yellow bands above foot. Back home, after looking at photos, we realized we had missed a band through binoculars and the actual bands were: Left leg - white, green with flag above knee, aluminum below knee; Right leg - white above two yellow, all below knee. The bird was observed $11: 20 \mathrm{~h}$ about 10 miles south of Pense.
Tracking this bird's origins took more time. The Bird Banding Laboratory apparently did not have the colour banding records as we received no information from them. However, thanks to the work of Jeannine M Parvin, Database Administrator at www. bandedbirds.org (email dated March 23, 2015) we learned that the Pectoral Sandpiper was a male and was banded on June 3, 2008 in the vicinity of Barrow Alaska (71.32 latitude, 156.67 longitude). This is near the northern tip of Alaska. She also advised that the band we reported as white on the right leg was light blue, or at least had been when it was placed on the bird. Reading band colours can be tricky!

Straight line distance from Barrow to where we observed the bird is $3,470 \mathrm{~km}$. Pectoral Sandpipers winter in South America, generally from Peru, $S$ Bolivia, S Brazil, N Argentina, and Uruguay south to central Chile and southernmost Argentina. ${ }^{1}$ The straight line distance from our 
observation to Lima Peru is 7,400 $\mathrm{km}$. So this Pectoral Sandpiper would have a one way migration of more than $10,800 \mathrm{~km}$. When we saw it, this little sandpiper had migrated south at least 6 times and was on at least its 6th trip north, meaning it would have flown a total of at least $126,000 \mathrm{~km}$ during migrations up to the time we saw it. Thinking of the energy burned to fly that far certainly gives a new appreciation for why shorebirds always seem to be feeding feverishly.

In June 2014 Paule observed a colour banded Piping Plover at Chaplin Lake. The red flag indicated that this bird was banded at Corpus Christ Texas in 2011 (email from David Nedstead, June 18, 2014). Straight line distance from Chaplin to Corpus Christi is $2,630 \mathrm{~km}$. This Piping Plover would have made the $5200 \mathrm{~km}$. round trip migration a minimum of 4 times when Paule observed it.

On July 19, 2015 we were taking the Shorebird Tour offered by the Chaplin Nature Centre. On a wetland connected to the south part of the lake along \#58 Highway, we observed godwits actively feeding in the wetland and occasionally flying up and then returning. Small flocks joined the original group until there were 28 Hudsonian Godwits and 61 Marbled Godwits. While observing and taking photographs we noticed that one Hudsonian Godwit was banded with a green flag labelled 1PM. As far as we could see it was the only banded bird in the flock.

We reported the observation to the Bird Banding Laboratory and were advised the Hudsonian Godwit had been banded on May 16, 2012, in Alaska at 61.25 latitude and 150.75 longitude. It was at least a year old when banded.

We soon heard from Garrett MacDonald (email August 11, 2015) who is involved in this ongoing study. He reported that "Female 1PM is part of a breeding population of Hudsonian Godwits that nests in the spruce bogs at Beluga, Alaska, a small, remote community about 45 miles southwest of Anchorage, Alaska on West Cook Inlet. Godwit research at Beluga was initiated in 2009 and has continued every season except for 2013." He added "There are approximately 30 breeding pairs of godwits in Beluga and the majority of breeding adults are banded and flagged (green flags with white engraved alpha-numeric codes either 2 or 3 digits long). 1PM was first banded as an adult in 2012 and has nested in Beluga every year since then (but researchers weren't there in 
2013). We know that she hatched chicks successfully in 2012, 2014, and 2015. We didn't find her nest this year but she was seen on our plot defending chicks on multiple occasions."

He also advised us that previous research with geolocators had shown most Hudsonian Godwits leaving their study site stopped in Saskatchewan for several weeks before continuing south. The flight from the Beluga study site to Saskatchewan is usually nonstop, which is $2,947 \mathrm{~km}$ if they followed a straight line to Chaplin. The study team think the Hudsonian Godwits moult during their fall stop in Saskatchewan and, of course, put on fat for the next part of the journey. That really emphasizes the importance of Chaplin Lake to these Hudsonian Godwits.

\section{Mr. MacDonald also advised that}

most of the Hudsonian Godwits from their study winter on Chiloé Island, Chile, South America (-42.4 latitude, -73.9 longitude) which is $10,780 \mathrm{~km}$ from Chaplin. In the spring they fly nonstop from Chiloe Island to the great plains of the United States. Hudsonian Godwits are clearly mighty flyers. Even if they flew in straight lines from Alaska to Chaplin and from Chaplin to Chiloé Island, that is a $13,000 \mathrm{~km}$ migration route one way.

1. Farmer A, Holmes RT and Pitelka FA (2013) Pectoral Sandpiper (Calidris melanotos), The Birds of North America Online (A. Poole, Ed.). Ithaca: Cornell Lab of Ornithology; Retrieved from the Birds of North America Online: http://bna.birds.cornell. edu.bnaproxy.birds.cornell.edul bna/species/348

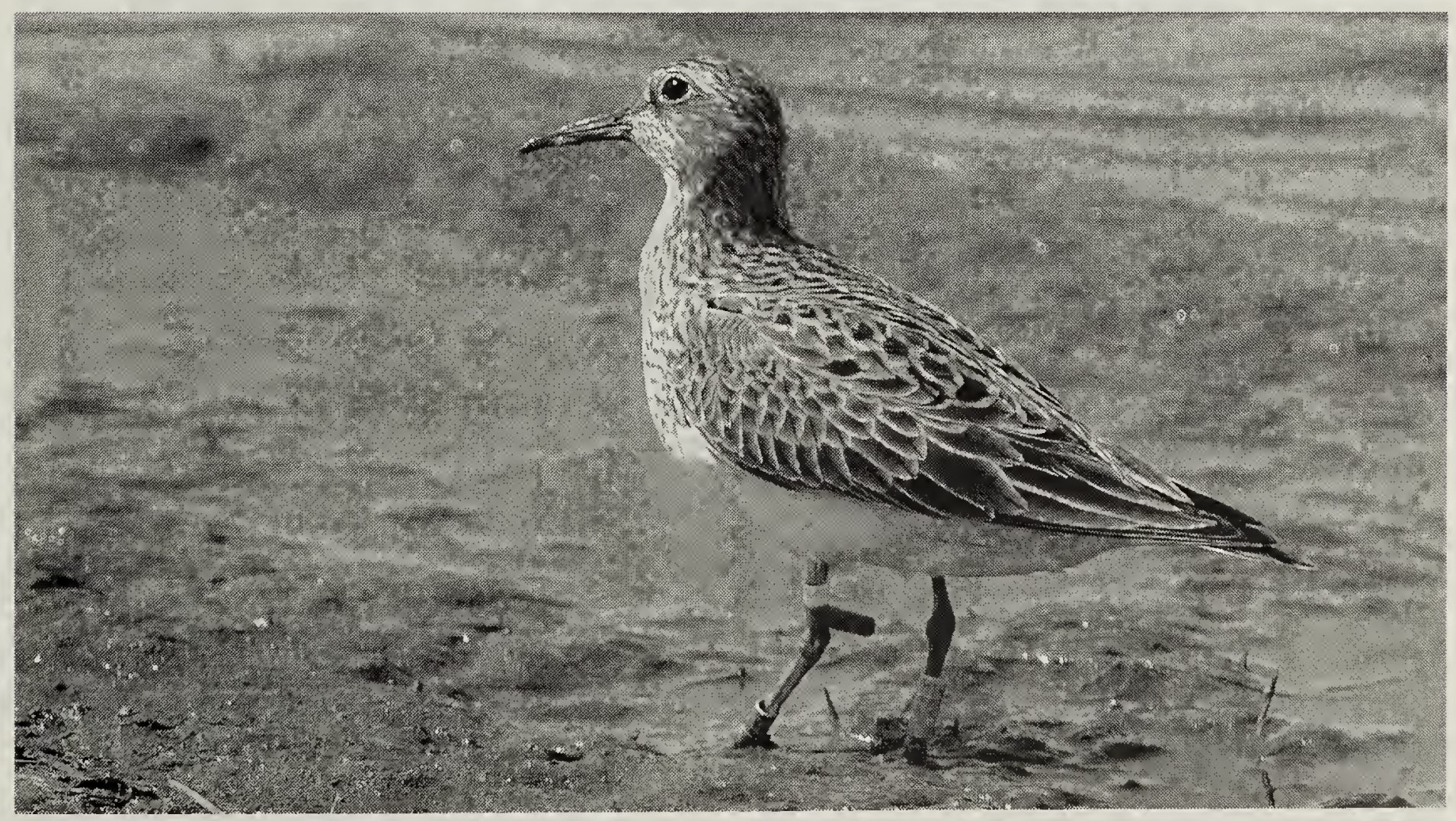






